Ĭgdır Üniversitesi Fen Bilimleri Enstitüsü Dergisi, 11(Özel Sayı): 3455-3464, 2021

Journal of the Institute of Science and Technology, 11(Special Issue): 3455-3464, 2021

Bitki Koruma / Plant Protection

ISSN: 2146-0574, eISSN: 2536-4618

DOI: 10.21597/jist.1027025

Araştırma Makalesi / Research Article

Geliş tarihi / Received: 22.11.2021

Kabul tarihi / Accepted: 14.12.2021

Atıf İçin: Köycü ND, 2021. Fusarium Başak Yanıklığının Buğday Kalite Parametreleri Üzerine Etkisi: Enfekteli Başaklara Fungisit Uygulamaları Sonrasındaki Değişim. Iğdır Üniversitesi Fen Bilimleri Enstitüsü Dergisi, 11(Özel Sayı): $3455-3464$.

To Cite: Köycü ND, 2021. The Effect of Fusarium Head Blight on Wheat Quality Parameters: Change After Fungicide Applicates in Infected-Spikes. Journal of the Institute of Science and Technology, 11(Special Issue): 3455-3464.

\title{
Fusarium Başak Yanıklığının Buğday Kalite Parametreleri Üzerine Etkisi: Enfekteli Başaklara Fungisit Uygulamaları Sonrasındaki Değişim
}

\section{Nagehan Desen KÖYCÜ}

ÖZET: Fusarium culmorum'un (Wm. G. Sm.) Sacc. tahıllarda fide yanıklığı (FSB), kök çürüklüğü ve başak yanıklı̆̆ına (FHB) neden olduğu enfeksiyonlar, dünyada ve aynı zamanda Trakya Bölgesi'nde de önemli bir sorundur. Bu çalışmanın amacı, $F$. culmorum'un buğday tanelerinde protein oranı (\%), tanecik boyutu (Particul Size Index), Zeleny sedimantasyon ( $\mathrm{ml})$, gluten $(\%)$ ve gluten index $(\%)$ kriterlerinin kalite parametreleri üzerine etkisini ve fungus ile enfekteli başaklara fungisit uygulamaları sonrasında tane kalite kriterlerindeki değişimi belirlemektir. Buğdayın antezis döneminde (ZGS 61), başaklara el spreyi ile fungusun spor süspansiyonu uygulaması yapılmıştır. Başaklara fungusun suni inokulasyonundan 48 saat sonra, prothioconazole+trifloxystrobin (Madison SC, Bayer CropScience, Türkiye), thiophanate-methyl+tetraconazole (Yamato SE, SumiAgro, Türkiye) ve tebuconazole (Rally SC 250, Agrofarm, Türkiye) etkili maddeleri el pulverizatörü ile uygulanmıştır. Deneme sonunda buğday tanelerinin kalite parametrelerindeki değişimi tespit edilmiştir. Fungisit uygulaması yapılan enfekteli başaklarla karşılaştııldığında, FHB ile enfekteli tanelerde de protein oranı içeriği değişmemiştir. Enfekteli tanelerde yaş gluten (\%), tanecik boyutu (PSI), Zeleny sedimantasyon miktarı (ml) ve gluten indeks (\%) değerleri kontrolle kıyaslandığında azalmıştır. Fungisitler arasında, prothioconazole+trifloxystrobin kalite parametreleri üzerinde en etkili fungisit olmuştur. Zeleny sedimantasyon ve yaş gluten arasındaki korelasyon pozitif ve önemli $(\mathrm{p}<0.01)$ bulunmuştur.

Anahtar Kelimeler: Fusarium culmorum, yaş gluten, protein oran1, Zeleny sedimantasyon, fungisit

\section{The Effect of Fusarium Head Blight on Wheat Quality Parameters: Change After Fungicide Applicates in Infected-Spikes}

ABSTRACT: The infections caused by seedling blight (FSB), root rot, and Fusarium head blight (FHB) of Fusarium culmorum (Wm. G. Sm.) Sacc. is a serious problem in cereal agriculture of the world as well the Trakya Region. The aim of this study was to determine the effect on protein rate (\%), Particle Size Index (PSI), Zeleny sedimentation ( $\mathrm{ml})$, wet gluten $(\%)$ and gluten index $(\%)$ on wheat kernels of $F$. culmorum and change of these quality parameters after applied fungicides. Spikes were the hand-sprayer pump-inoculated with conidial suspension of the fungus at the anthesis stage (ZGS 61) of wheat. Prothioconazole+trifloxystrobin (Madison SC Bayer CropScience, Türkiye), thiophanate-methyl+tetraconazole (Yamato, SumiAgro, Türkiye) ve tebuconazole (Rally SC 250, Agrofarm, Türkiye) active ingredients were applied $48 \mathrm{~h}$ post-inoculation of fungi with a handgarden sprayer. At the end of the experiment, quality parameters of wheat kernels were measured. Protein rate contents also did not change in FHB infected-kernels compared to applicated-fungicide parcels. Wet gluten (\%), Particle Size Index (PSI), Zeleny sedimentation (ml) and gluten index (\%) were decreased in infected-kernels compared to control kernels. Among fungicides, prothioconazole+trifloxystrobin was the most effective fungicide on quality parameters. Zeleny sedimentation and gluten were significant and positive $(\mathrm{p}<0.01)$.

Keywords: Fusarium culmorum, wet gluten, protein rate, Zeleny sedimantation, fungicide

${ }^{1}$ Nagehan Desen KÖYCÜ (Orcid ID: 0000-0003-2511-6096), Tekirdağ Namık Kemal Üniversitesi, Ziraat Fakültesi Bitki Koruma Bölümü, Tekirdağ, Türkiye

*Sorumlu Yazar/Corresponding Author: Nagehan Desen KÖYCÜ, e-mail: dkoycu@nku.edu.tr

Bu çalışma 15-17 Kasım 2021 tarihlerinde Iğdır'da düzenlenen 'Uluslararası Katılımlı Türkiye 7. Tohumculuk

Kongresi'nde' sözlü olarak sunulmuştur. 


\section{GíRIŞ}

Fusarium tahıllarda fide yanıklığı, kök çürüklüğü ve başak yanıklığı gibi önemli hastalıklara neden olan parazitik-saprotrofik yaşam tarzlarına sahip önemli bir fungus cinsidir. Bu cins buğdayın en önemli patojenleridir (Wang ve ark., 2020; Trail, 2009; Bottalico ve Perrone, 2002). Fusarium başak yanıklı̆̆ (FHB), F. culmorum, F. graminearum, F. avenaceum ve F. pseudograminearum gibi birkaç Fusarium türünün neden olduğu bir hastalık kompleksi olarak adlandırılır. Buğdayda, Fusarium başak yanıklığ (FHB), tahıl üretim ve satışında milyarlarca dolar zarara neden olabilmektedir (Bottalico ve Perrone, 2002, Foroud ve Eudes, 2009; Marin ve ark., 2013) Çin, Amerika Birleşik Devletleri ve Kanada gibi ülkelerde buğdaydaki verim kayıplarının ana nedeninin FHB olduğu tespit edilmiştir (Anonymous, 2007). Buğdayda Fusarium solgunluğunun neden olduğu fide yanıklığg, kök çürüklüğü ve Fusarium başak yanıklığı (FHB) özellikle bitki büyümesi, gelişmesi, tane verimi ve kalitesi üzerinde olumsuz etkilere neden olmaktadır (Xu ve Nicholson 2009; Salgado ve ark., 2014; Wang ve ark., 2020) Aynı tarz ürün rotasyonu uygulanması, toprak işlemesinin iyi yapılmaması ve iklim değişikliği ile birlikte hastalık riski gittikçe artmıştır (Streuter ve ark., 1989; Gaudet ve ark., 1999; Morkunas ve ark., 2005; Tarkowski ve ark., 2019). Fusarium başak enfeksiyonu, çiçeklenme döneminde tek bir başakçı̆̆ın enfekteli olmasıyla tüm başaklara bulaşabilmekte ve başak kavuzlarında pembe-kırmızı renkteki sporodochia yatakları fungusun sporlarının kaynağı olarak diğer başaklar için bir hastalık tehdidi oluşturabilmektedir. Beyaz başak semptomlarına neden olarak başakçık içerisindeki tanelerin cılız ve buruşuk gelişme göstererek buğdayın tane kalitesini olumsuz yönde etkileyebilmektedir (Bai, 1995). Fusarium deoksinivalenol (DON), nivalenol (NIV), T-2 toksini ve zearalenon (ZEN) gibi çok sayıda tehlikeli mikotoksinlerini üretir. Bu mikotoksinler, trikotesen ailesinden yani patojenik virülans ve protein oranı sentezinden sorumlu epoksi-seskiterpenoid metabolitleri temsil eder (Scherm ve ark., 2013) $F$. culmorum'un bu metabolitleri ile kontamine olmuş g1da ürünleri ile beslenen insanlara ve hayvan yemleri beslenen hayvanlara ciddi ve kronik zararlar verebilmektedir (Bottalico ve ark., 2002; Foroud ve Eudes, 2009; Marin ve ark., 2013). Bu nedenle Fusarium başak yanıklığına karşı fungisit uygulamalarının yapılması yüksek hastalık şiddetinin ve etmenin mikotoksin üretiminin önlenmesi açısından önemlidir (Scherm ve ark., 2013). Bu hastalık etmenine karşı azol (bromuconazol, siproconazol, metconazol, procloraz, propiconazol, protioconazol ve tebuconazol) ve strobin (azoxystrobin) sınıflarına ait olan çeşitli fungisitlerin, tarlada hastalığ $\%$ 70'e varan oranlarda kontrol ettiği belirlenmiştir. (Chala ve ark., 2003; Jones, 2000; Paul ve ark., 2008; González-Domínguez ve ark., 2021)

Trakya Bölgesi’nde kök ve kök boğazı hastalığının uzun yıllardan beri sorun olduğu bilinmektedir (Finci, 1979; Hekimhan, 2010). Bununla birlikte kök, kök boğazı ve başak yanıklığına neden olan Fusarium culmorum (Wm. G. Sm.) Sacc. Trakya Bölgesi'nde buğdayda en yaygın olarak görülen ve yüksek hastalık şiddetine sahip Fusarium türü olarak bilinmektedir (Hekimhan 2010; Köycü ve Özer 2019). Tohum yoluyla taşınabilen Fusarium culmorum başak yanıklığı (FHB) buğdayda yüksek hastalık şiddetine neden olarak hasat döneminde tane verimini önemli derecede azaltmaktadır (Scherm ve ark., 2013). İnsan beslenmesinde önemli bir yere sahip olan buğday veriminin yanında kalitesinin de yükseltilmesi çok önemlidir. Buğday kalitesi, iklim, toprak, çeşit gibi farklı faktörlere bağlı olan (Peterson ve ark., 1992; Atlı, 1999) ve çok sayıda genin kontrol ettiği kantitatif bir karakterdir. Islahçılar buğdayda kalite parametreleri olan genotiplerinde bin tane ağırlı̆̆ protein oranı gluten kalitesi gibi özelliklerini seleksiyon kriterleri olarak kullanmaktadırlar. Ekmekte kaliteyi etkileyen en önemli faktör olarak tanede protein oranının, gluten miktarının ve Zeleny sedimantasyon değerinin yüksek olmasıdır (Goesaert ve ark., 2005; Kahraman ve Öztürk, 2008; 
Miadenow ve ark., 2001). Fusarium ile bulaşık tanelerin besin içeriği yönünden zayıfladığı (Bechtel ve ark., 1985), nişasta granüllerinin, depo protein oranlarının ve hücre duvarının patojen tarafından parçalandığı dolayısıyla karbonhidrat ve protein oranlarının tane içerisinde etkilendiği saptanmıştır (Nightingale 1999). Bu nedenle Trakya bölgesinde yaygın ve yüksek hastalık şiddetine sahip olan buğdayın başak yanıklığı etmeni $F$. culmorum'un buğdayda kalite parametreleri olan protein oranı (\%), tanecik boyutu (Particul Size Index), Zeleny sedimantasyon (ml), gluten (\%) ve gluten index (\%) miktarları üzerine etkisi ve Fusarium culmorum ile enfekteli başaklara prothioconazole+trifloxystrobin, thiophanate-methyl+tetraconazole ve tebuconazole etkili maddeli fungisit uygulamaları sonrasında kalite parametrelerindeki değişim bu çalışmanın amacını oluşturmuştur.

\section{MATERYAL VE METOT}

\section{Materyal}

\section{Flamura-85 çeşidi}

Denemede Fusarium culmorum'a hassas olan Flamura 85, Tareks A.Ş. tarafindan 1999 yılında tescil ettirilen Romanya orijinli ekmeklik buğday çeşidi kullanılmıştır. Bu çeşit orta erkenci, orta boylu, sağlam saplı olarak yatmaya dayanıklı, başakları uzun olup yarı eğik bir görünümlü, beyaz başaklı, kılçıklı ve bitki boyu 85-95 cm'dir. Tanesi kırmızı sert ve iri yapıda olup ekmeklik kalitesi çok iyi olan kışlık bir çeşit olup soğuğa dayanıklılığı iyi olduğu için Marmara Bölgesi ile kışlık ekim yapılan diğer bölgelerde taban ve yarı taban alanlarda ekimi tavsiye edilmektedir. Kardeşlenme kapasitesi iyi olup verim potansiyeli orta veya yüksektir (350-600 kg/da). Kullanılacak tohumluk miktarı $\mathrm{m}^{2}$ 'ye 450-550 tane (18-20 kg/da) olarak önerilmektedir. Bin dane ağırlığ 37-41 g, hektolitre ağırlığ1 78-82 kg, protein oran1 \%13-14 ve un verimi \%60- 70'dir.

\section{Fusarium culmorum izolatı}

Denemede daha önceden patojen olduğu (Köycü ve Özer 2019) ve deoxynivalenol (DON) toksinini salgıladığı tespit edilmiş F. culmorum S-14 izolatı kullanılmıştır (Pasquali ve ark., 2016).

\section{Fungisitler}

Denemede prothioconazole+trifloxystrobin (Madison SC 263, $100 \mathrm{ml} / \mathrm{da}$, Bayer CropScience, Türkiye), thiophanate-methyl+tetraconazole (Yamato $175 \mathrm{ml} / \mathrm{da}$, SumiAgro, Türkiye) ve tebuconazole (Rally EC 250, 75 ml/da, Agrofarm, Türkiye) etkili maddeli fungisitler kullanılmıştır.

\section{Metot}

Tarla koşullarında anthesis (ZGS 61) (Zadoks ve ark.,1974) dönemindeki Flamura 85 buğday çeşidine $F$. culmorum S-14 izolatı $1 \times 10^{5} \mathrm{konidi} / \mathrm{ml}$ oranıyla el atomizörü kullanılarak yapay olarak inokule edilmiştir (Haidukowski ve ark., 2012). Yapay inokulasyon yapılan başaklar şeffaf polietilen torba ile örtülerek 48 saat süre ile inkübasyona bırakılmıştır. İnkübasyon süresi sonunda başaklara prothioconazole+trifloxystrobin, thiophanate-methyl+tetraconazole ve tebuconazole etkili maddeli fungisitler el pompası kullanılarak uygulanmıştır. Deneme parsel genişliği 1m, parsel uzunluğu $5 \mathrm{~m}$ ve sıra arası mesafe ise 0,17 m olacak şekilde buğday üretici arazisinde tesadüf blokları deneme desenine göre üç tekerrürlü olarak 2016-2017 üretim döneminde kurulmuştur.

\section{Kalite analizleri}

Deneme hasat edildikten sonra temizlenmiş ve her parselden elde edilen üründen alınan $1 \mathrm{~kg}{ }^{\prime} l 1 \mathrm{k}$ örneklerde protein oranı (\%), tanecik boyutu (PSI), Zeleny sedimantasyon (ml), yaş gluten (\%) ve gluten index (\%) değerleri Edirne Ticaret Borsası laboratuvarında belirlenmiştir. 


\section{Protein oranı $(\%)$}

Kjeldahl metoduna (AACC 46-10) göre protein miktarları tespit edilmiştir. Ekmeklik buğday kırmaları ile kalibrasyonu yapılmış NIR (Near Infra Red) spektroskopi cihazında yüzde (\%) olarak tanede protein oranı okumaları tamamlanmıştır (Anonymous 1990).

\section{Tanecik boyutu (PSI)}

Buğdayda sertlik (Particul Size Index) Perten PerCON Inframatik 8600 ASH NIR marka Near Infra Red Reflektans Spektroskopi kullanılarak analiz edilmiştir (Anonymous, 1990).

\section{Zeleny sedimantasyon değeri (ml)}

Her parselden alınan 10 gram tane örneğinin ögütülmesiyle elde edilen undan 3,2 g tartılmış ve üzerine $50 \mathrm{ml}$ bromfenol mavili su konulup 200 devirde $5 \mathrm{dk}$. çalkalanmıştır. Üzerine $25 \mathrm{ml}$ test çözeltisi (laktik asit+izopropil+su karışımı) ilave edilerek tekrar çalkalama aletinde $5 \mathrm{dk}$ çalkalanmıştır. Aletten alınan tüpler $5 \mathrm{dk}$ bekletildikten sonra tüp içinde çökmüş olan un seviyesi tüp üzerindeki işaretli kısımdan okunmuş ve Zeleny sedimantasyon değeri ml olarak belirlenmiştir.

\section{Yaş gluten oranı (\%)}

Analizde 10'ar gram un hazırlanmış ve örnekler nişasta ve diğer bileşenlerinden yıkanması amacıyla \%2'lik tuzlu suda 5 dakika süre ile bekletildikten sonra geriye kalan gluten tartılıp yaş öz olarak kaydedilmiştir. Daha sonra Glutomatik (Perten Unstrumental AB) aleti ile ICC No:155'e göre tespit edilmiştir (Anonymous 1994).

\section{Gluten index $(\%)$}

Analizde 10'ar gram un örnekleri \%2'lik tuzlu su ile 5 dakika süre ile nişasta ve diğer bileşenleri yıkanmış, elde edilen gluten Perten Santrifüj'de 1 dakika süreyle santrifüj edilmiştir. Sağlam kalan kısım bütün gluten miktarına oranlanarak gluten indeksi bulunmuştur (Perten, 1990).

\section{BULGULAR VE TARTIŞMA}

Protein oranı (\%), yaş gluten miktarı (\%), tanecik boyutu (PSI) Zeleny sedimantasyon (ml) ve gluten index (\%) kalite parametrelerinin sonuçları Şekil 1'de verilmiştir. Protein oranı (\%) oranları tüm uygulamalarda yaklaşık \%14 olarak tespit edilmiştir. Fusarium culmorum ile yapay olarak inokule edilen başaklardan elde edilen tane ürününde yaş gluten (\%), sertlik (PSI), Zeleny sedimantasyon (ml) ve gluten index (\%) değerlerinin en düşük olduğu belirlenmiştir. Prothioconazole+trifloxystrobin ve tebuconazole uygulanmış başaklar Fusarium culmorum ile yapay inokule edilmiş ve fungisit uygulaması yapılmamış başaklar ile karşılaştırıldığında sertlik, Zeleny sedimantasyon, yaş gluten ve gluten index miktarı oranlarında artış tespit edilmiştir. Enfekteli başaklara prothioconazole+trifloxystrobin etkili maddeli fungisit uygulaması ise kalite parametreleri üzerinde en yüksek yüzde artışa neden olarak, enfekteli başakla kıyaslandığında sertlikte \%3.77, Zeleny sedimantasyonda \%27.90, yaş glutende $\% 5.15$ ve gluten indekste ise \%10.54 oranında bir artış tespit edilmiştir. 

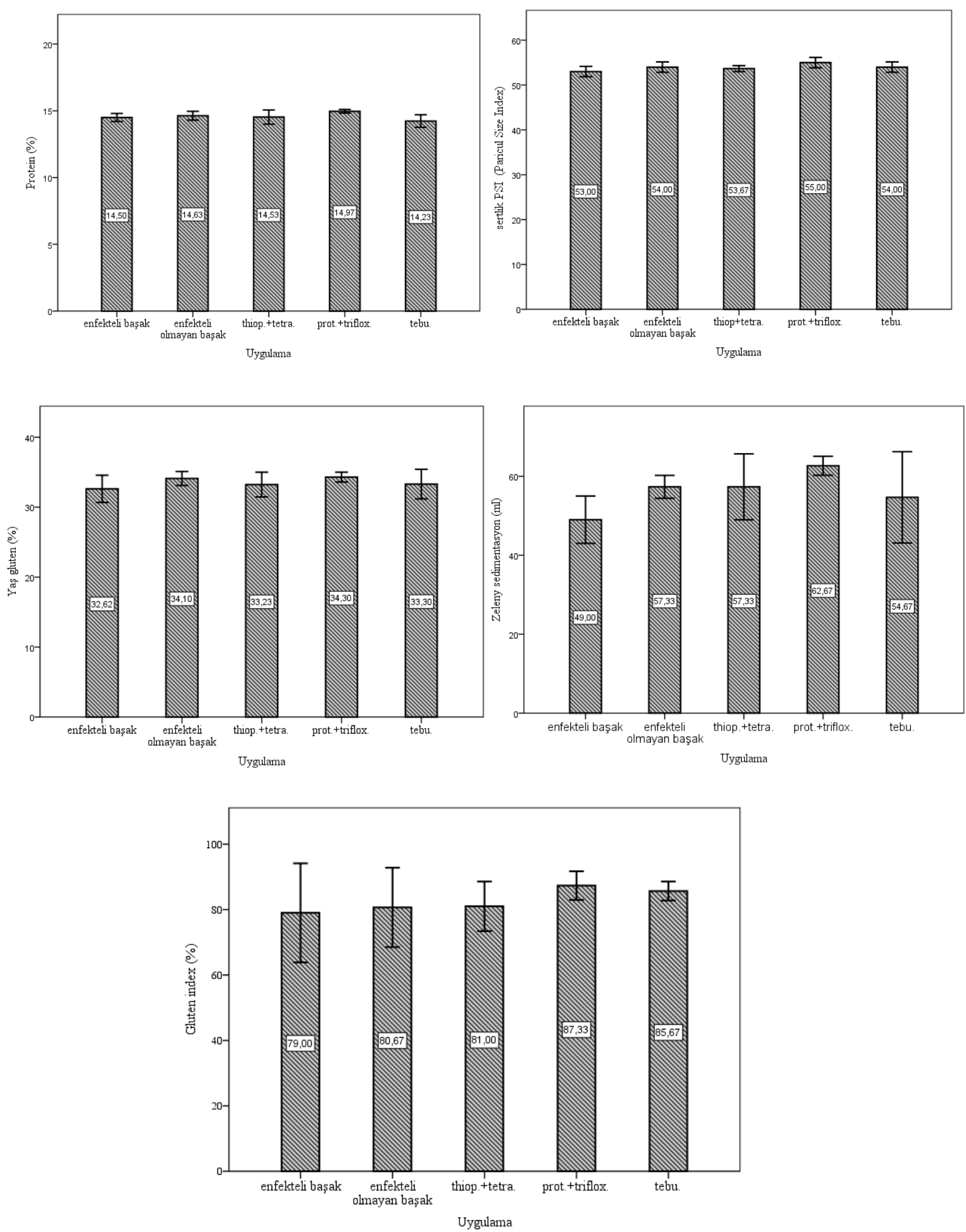

Şekil 1. Fusarium culmorum ile enfekteli başaklarda thiop+tetra. (thiophanate+tetraconazole), prot.+triflox. (prothioconazole+trifloxystrobin) ve tebu. (tebuconazole) etkili maddeli fungisit uygulaması yapılan enfekteli başaklar ve enfekteli olmayan başaklardaki tanelerde protein oranı (\%), yaş gluten (\%), tanecik boyutu (PSI), Zeleny sedimantasyon (ml) ve gluten index (\%) kalite parametrelerinin dağılımı. Bar çubukları ortalama standart hatayı $( \pm)$ temsil etmektedir 
Tanedeki Zeleny sedimantasyon (ml) ve gluten (\%) miktarları arasında pozitif doğrusal bir ilişki bulunmuştur (Şekil 2). Zeleny sedimantasyon ve gluten arasındaki korelasyon katsayısı 0.717 ve $p<0.01$ düzeyinde önemli olarak tespit edilmiştir.

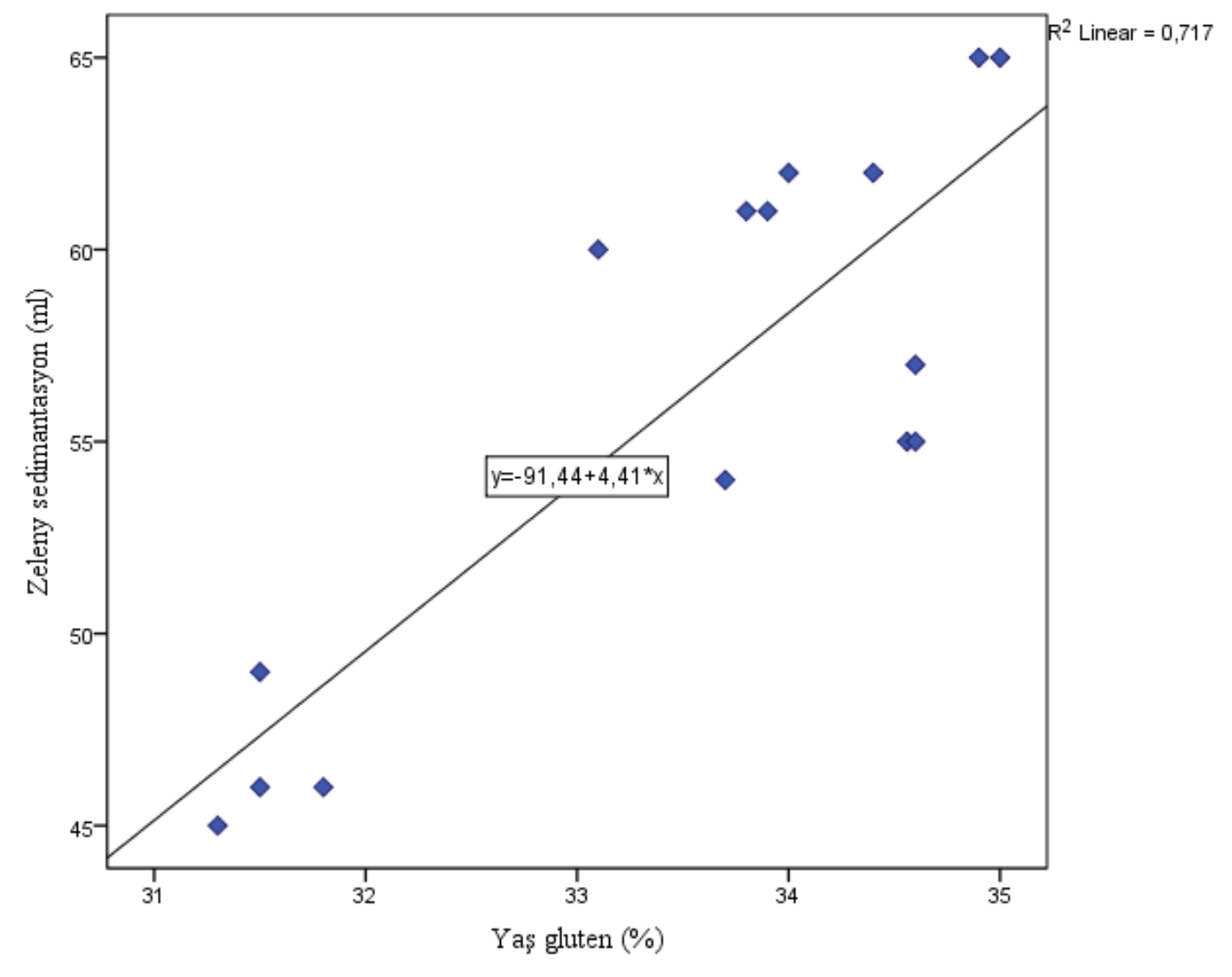

Şekil 2. Buğday tanelerinde Zeleny sedimantasyon (ml) ve yaş gluten (\%) değerleri arasındaki korelasyon

Buğdayın kalite kriterlerinin değerlendirilmesinde kullanılan analitik ölçütler arasında en sık kullanılanlar; protein oranı, Zeleny sedimantasyon ve yaş gluten miktarıdır. Bununla birlikte kalite özelliklerini belirlemede dünyada ve ülkemizde farklı kriterler de ele alınabilmektedir. Amerika, Kanada ve Avustralya buğday üretiminde ve ihracatında buğdayın kalite sınıflandırmasında genellikle renk, sertlik ve yazlık/kışlık olma durumunu göz önüne almaktadır (Góral ve ark., 2018). Ülkemizde ise ekmeklik buğday kalitesini belirlemede protein oranı miktarı, Zeleny sedimantasyon değeri, yaş gluten, kuru gluten ve gluten indeksi yaygın olarak kullanılan parametre değerleridir (Wang ve ark., 2020). Toprak Mahsulleri Ofisi buğday kalitesini ve alım fiyatlarını fiziksel parametreler (kırık tane, cılızburuşuk tane, süne tahribatına uğramış tane, embriyosu kararmış tane, diğer hububat, yabancı madde vb.) ve analitik parametreleri (protein oran1) içeren bir indeksle belirlemektedir. Bu kalite parametrelerinden yaş gluten miktarı ile protein oranı arasında doğrusal bir ilişki olduğu (Trail, 2009), undaki Zeleny sedimantasyon değerinin buğdayın protein oranı miktarıyla ilişkili olduğu bilinmektedir (Bottalico ve ark., 2002). Gluten ekmek hamurunun elastik olmasını sağlamaktadır (Wieser, 2007). Fermentasyon sırasında maya tarafından üretilen karbondioksit gazının tutulmasını sağlayarak ekmeğin hacimli olması üzerinde etkili olan glütenin yüzde değerinin yüksek olması istenmektedir (Mutlu, 2020). Zeleny sedimantasyon değeri ise gluten kalitesini (gluten yapısı, un kuvveti) belirlemektedir (Mutlu, 2020). Tanenin sertlik durumunu belirleyen tanecik boyutu taneyi kırma ve öğütme sırasında sarf edilen enerjiyi belirlediği için değirmencilik kalitesi ve irmik verimi bakımından önemlidir. Bu nedenle sert buğdayların irmik verimi ve enerji sarfiyatı yüksektir (Okur, 2017). Ekmeklik ve makarnalık 
buğdaylarda sertlik aranan bir özellik olarak protein oranı ve nişasta ile ilgilidir. Protein yüzeyi hidrofobiktir ve protein ağları sert buğdaylarda nişastanın çevresini sarmaktadır (Troccoli ve ark., 2000; Turnbull ve Rahman, 2002). Protein oranı ve gluten miktarı ile birlikte Zeleny sedimantasyon değerinin ölçülmesi buğday unu karakterizasyonu açısından gereklidir (Bennett ve Klich, 2003).

FHB ile bulaşık taneler küçük ve buruşuktur ve endospermde kepek oranı da düşmektedir. Khalil ve ark., (2002) FHB ile bulaşık tanelerde protein oranının kontrollere kıyasla yüksek çıtı̆̆ını tespit etmiştir. Bunun nedeninin ise fungusun tanelerde yüksek oranda karbonhidrat tüketmesi ile protein oranının yüksek olması sonucu olduğunu açıklamışlardır. Mert Türk ve ark., (2013) ise FHB ile bulaşık tanelerde, kontrollere kıyasla protein oranı açısından bir farklılık oluşmadığını, fakat tanelerde karbonhidrat içeriğinin istatistiki olarak düştügünü tespit etmiştir. F. culmorum ile enfekteli tanelerde prothioconazole+trifloxystrobin, thiophanate-methyl+tetraconazole ve tebuconazole etkili maddeli fungisit uygulaması yapılan ve yapılmayan tanelerde protein oranlarının birbirine yakın olduğu tespit edilmiştir ve bu sonuç Mert Türk ve ark., yaptığı çalışma sonucu ile uyum göstermiştir. Gluten miktarı yüksek ve gluten kalitesi iyi olduğunda yüksek Zeleny sedimantasyon değerleri gözlenmiştir (Hruskova ve ark., 2003). Araştırmamızda Zeleny sedimantasyon (ml) ve gluten (\%) miktarları arasındaki korelasyon değerinin yüksek olduğu tespit edilerek Hruskova ve ark., yaptığı çalışma ile uyum göstermiştir. F. culmorum ile enfekteli başaklara uygulanan prothioconazole+trifloxystrobin ve tebuconazole etkili maddeli fungisitlerin tane kalitesini artırmada etkili olduğu belirlenmiştir. Yapılan bu araştırmada kullanılan $F$. culmorum S-14 izolatının DON (Deoxynivalenol) mikotoksinini salgıladığ daha önce yapılan bir çalışma ile tespit edilmiştir (Pasquali ve ark., 2016). Bu mikotoksinin insan ve hayvan sağlığı üzerindeki olumsuz etkileri göz önüne alındığında fungisit uygulamaları sonrasındaki tane kalite kriterlerine olumlu etkilerinin önemini düşündürmektedir.

\section{SONUÇ}

Bu çalışmada Fusarium culmorum ile enfekteli tanelerde hastalık etmeninin tane kalitesini düşürdüğü, bununla birlikte başak yanıklığına karşı fungisit uygulamasının tanelerde tane kalitesini artırdığ1 görülmektedir. Prothioconazole+trifloxystrobin etkili maddeli fungisit uygulamasının Fusarium culmorum ile enfekteli olmayan tane ile karşılaştırıldığında sertlik (PSI), yaş gluten (\%), Zeleny sedimantasyon ( $\mathrm{ml}$ ) ve gluten index (\%) değerlerini artırdığı, tane kalitesi üzerine olumlu katk1 sağladığı tespit edilmiştir. Fusarium culmorum ile enfekteli tanelerde un kalitesinin değişebileceği göz önüne alındığında hastalık etmeni ile enfekteli tanelerdeki kalite kriterlerinin detaylı çalışılması gerekmektedir.

\section{TEŞEKKÜR}

$\mathrm{Bu}$ çalışmanın yürütülmesinde kendi tarla arazisinde denemenin kurulmasını sağlayarak denemedeki her türlü yardımları için Özgür Uzel'e, arazi çalışmalarındaki katkı ve yardımlarından dolayı Füsun Sukut'a, Fusarium culmorum ile enfekteli buğday bitki örneklerinin toplanabilmesi için Trakya Bölgesi'nde buğdayda tarla surveylerinin arazi çıkışlarında sağladıkları imkanlar için Tekirdağ Namık Kemal Üniversitesi Ziraat Fakültesi Tarla bitkileri öğretim üyelerinden Prof. Dr. Oğuz Bilgin ve Doç. Dr. Alpay Balkan'a çok teşekkür ediyorum.

\section{Çıkar Çatışması}

Makalenin planlanması ve yazılması sırasında herhangi bir çıkar çatışması olmadığını beyan ederim. 


\section{Yazar Katkısı}

Makalenin planlanması, yürütülmesi ve yazılmasının tarafımdan yapıldı̆̆ını beyan ederim.

\section{KAYNAKLAR}

Anonymus 1990. Approved Methods of the American Association of Cereal Chemist, USA.

Anonymous 1994. ICC Standard No 155: Determination of Wet Gluten Quantity and Quality (Gluten Index ac. To Perten) of Whole Wheat Meal and Wheat Flour.

Anonymous, 2007. Commission Regulation (EC) No 1126/2007 of 28 September 2007 Amending Regulation (Ec) No 1881/2006 Setting Maxi-Mum Levels For Certain Contaminants in Foodstuffs As Regards Fusarium Toxins in Maize and Maize Products (Text with EEA Relevance). https://eurlex.europa.eu/legalcontent/EN/ALL/uri=CELEX:32007R1126 (erişim tarihi 2 Şubat 2021).

Atlı A, 1999. Buğday ve Ürünleri Kalitesi. Orta Anadolu'da Hububat Tarımının Sorunları ve Çözüm Yolları Sempozyumu. S. 498-506 (8-11 Haziran) Bildirileri. Konya.

Bai G, 1995. Scab of Wheat: Epidemiology, Inheritance of Resistance and Molecular Markers Linked to Cultivar Resistance. Ph.D. Thesis. West Lafayette, IN, USA, Purdue University.

Bechtel DB, Kaleikau LA, Gaines RL, Seitz LM, 1985. The Effects of Fusarium graminearum Infection on Wheat Kernels. Cereal Chemistry, 62:191-197.

Bennett JW, Klich, M, 2003. Mycotoxins. Clinic Microbiology Review, 16:497-516.

Bottalico A, Perrone G, 2002. Toxigenic Fusarium Species and Mycotoxins Associated with Head Blight in Small-grain Cereals in Europe. Mycotoxins Plant Disease, 108:611-624.

Chala A, Weinert J, Wolf GA, 2003. An Integrated Approach to the Evaluation of the Efficacy of Fungicides Against Fusarium culmorum, the Cause of Head Blight of Wheat. Journal of Phytopathology, 151:673-678.

Finci S, 1979. Buğdayın Kök ve Kök-Boğazı Hastalıkları ve Korunma Çareleri. Gıda Tarım ve Hayvancılık Bakanlığı Zirai Mücadele ve Zirai Karantina Genel Müdürlüğü, Çiftçi Broşürü No: 21, s, 15 .

Foroud NA, Eudes F, 2009.Trichothecenes in Cereal Grains. International Journal Molecular Science, 10:147-173.

Gaudet DA, Laroche A, Yoshida M, 1999. Low Temperature-Wheat-Fungal Interactions: A Carbohydrate Connection. Physiologia Plantarum, 106:437-444.

Góral T, Wiśniewska H, Ochodzki P, Nielsen LK, Walentyn-Góral D, Stępień Ł, 2018. Relationship Between Fusarium Head Blight, Kernel Damage, Concentration of Fusarium Biomass, and Fusarium Toxins in Grain of Winter Wheat Inoculated with Fusarium culmorum. Toxins, 11, 2.

Goasaert H, Brijs K, Veraverbeke WS, Courtin CM, Gebruers K, Delcour JA. 2005. Wheat Flour Constituents: How They Impact Bread Quality, and How to Impact their Functionality. Trends in Food Science and Technology, 16:12-30.

González-Domínguez E, Meriggi P, Ruggeri M, Rossi V, 2021. Efficacy of Fungicides Against Fusarium Head Blight Depends on the Timing Relative to Infection Rather than on Wheat Growth Stage. Agronomy, 11(8): 1549.

Hekimhan H, 2010. Trakya Bölgesinde Buğdaylarda Kök ve Kök Boğazı Çürüklügüune Neden Olan Fungal Etmenler ve Patojenisitelerini Etkileyen Bazı Faktörler Üzerine Araştırmalar. Doktora Tezi, Selçuk Üniversitesi Fen Bilimleri Enstitüsü, Konya. 
Haidukowski M, Visconti A, Perrone G, Vanadia S, Pancaldi D, Covarelli L, Balestrazzi R, Pascale M, 2012. Effect of Prothioconazole-based Fungicides on Fusarium Head Blight Grain Yield and Deoxynivalenol Accumulation in Wheat Under Field Conditions. Phytopathologia Mediterranea, 51(1):236-246.

Hruskova M, Famera O, 2003. Prediction of Wheat and Flour Zeleny Sedimantation Value Using NIR Technique, Czech Journal of Food Science, 21:91-96.

Jones RK, 2000 Assessments of Fusarium Head Blight of Wheat and Barley in Response to Fungicide Treatment. Plant Disease, 84:1021-1030.

Kahraman T, Avcı R, Öztürk İ, 2008. Islah Çalışmaları Sonucu Geliştirilen Bazı Ekmeklik Buğday Hatlarının Tane Verimi ve Bazı Kalite Özelliklerinin Belirlenmesi. Ülkesel Tahıl Sempozyumu, 2-5 Haziran 2008, KONYA.

Khalil IH, Carver BF, Krenzer EG, MacKown CT, Horn GW, 2002. Genetic Trends in Winter Wheat Yield and Test Weight Under Dual Purpose and Grain Only Management. Crop Science, 710-715. Köycü ND, Özer N, 2019. Trakya Bölgesi’nde Bazı Buğday Çeşitlerinin Fusarium spp. İzolatlarına Karşı Dayanıklılığın Tespit Edilmesi. KSÜ Tarım ve Doğa Dergisi, 22(4): 498-505.

Marín S, Ramos AJ, Cano-Sancho G, Sanchis V, 2013. Mycotoxins: Occurrence, Toxicology, and Exposure Assessment. Food Chemistry Toxicology, 60:218-237.

Mert Türk F, Kahraman F, Gencer R, Egese CÖ, 2013. Fusarium Başak Yanıklığının Buğdayda Toplam Protein Oranı ve Karbonhidrat İçeriğine Etkisi. Yüzüncü Yı1 Üniversitesi Tarım Bilimleri Dergisi, 23(2): 149-153.

Miadenow N, Przulj N, Hristov N, Djuric V, Milovanovic M, 2001. Cultivar-by-Enviroment Interactions for Wheat Quality Traits in Semiarid Conditions. Cereal Chemistry, 78, 363-367.

Morkunas I, Marczak Ł, Stachowiak J, Stobiecki M, 2005. Sucrose-1nduced Lupine Defense Against Fusarium oxysporum: Sucrose-stimulated Accumulation of Isoflavonoids as a Defense Response of Lupine to Fusarium oxysporum. Plant Physiology Biochemistry, 43:363-373.

Mutlu A, 2020. Buğdayda Kalite Kriterleri (edt: N. Yarpuz Bozdoğan; Ziraat Orman ve Su Ürünleri Alanında Teori ve Araştırmalar. Gece Kitaplığı, Bölüm;14.

Nightingale M, Marchylo BA, Clear RM, Dexter JE, Preston KR, 1999. Fusarium Head Blight: Effect of Fungal Protease on Wheat Storage Protein Oran1. Cereal Chemistry, 76:150-158.

Okur Y, 2017. Ekmeklik Buğday Kalitesini Değerlendirmede Kullanılan Kimyasal ve Fiziksel Özelliklerin İncelenmesi. Hacettepe Üniversitesi Fen Bilimleri Enstitüsü, Yüksek Lisans Tezi, s70.

Pasquali M, Beyer M, Logrieco A, Audenaert K, BalmasV, Basler R, Boutigny A-L, Chrpova J, Czembor E, Gagkaeva T, Gonzales-Jaen MT, Hofgaard IS, Köycü ND, Hoffman L, J. Levic, Marin P, Miedaner T, Migheli Q, Moretti A, Müller MEH, Munaut F, Parikka P, Pallez-Barthel M, Piec J, Scauflaire J, Scherm B, Stankovic S, Thrane U, Uhlig S, Vanheule A, Yli_Mattila T and Vogelgsang S 2016. A European Database of Fusarium graminearum and F. culmorum Trichothecene Genotypes. Frontiers in Microbiology, 7: 406.

Paul PA, Lipps, PE, Hershman DE, McMullen MP, Draper MA, Madden LV, 2008. Efficacy of TriazoleBased Fungicides for Fusarium Head-Blight and Deoxynivalenol Control in Wheat: A Multivariate Meta-analysis. Phytopathology, 98: 999-1011. 
Pasquali M, Beyer M, Logrieco A, Audenaert K, BalmasV, Basler R, Boutigny AL, Chrpova J, Czembor E, Gagkaeva T, Gonzales-Jaen MT, Hofgaard IS, Köycü ND, Hoffman L, Levic J, Marin P, Miedaner T, Migheli Q, Moretti A, Müller MEH, Munaut F, Parikka P, Pallez-Barthel M, Piec J, Scauflaire J, Scherm B, Stankovic S, Thrane U, Uhlig S, Vanheule A, Yli_Mattila T and Vogelgsang S, 2016. A European Database of Fusarium graminearum and F. culmorum Trichothecene Genotypes. Frontiers in Microbiology, 7: 406.

Peterson CJ, Graybosch RA, Baezinger PS, Grombacher AW, 1992. Genotype and Environment Effects on Quality Characteristics of Hard Red Winter Wheat. Crop Science, 32: 98-103.

Perten H 1990. Rapid Measurement of Wheat Gluten Quality by the Gluten Index. Cereal Foods World, 35:401-402.

Salgado JD, Madden L, Paul PA, 2014. Efficacy and Economics of Integrating in Field and Harvesting Strategies to Manage Fusarium Head Blight of Wheat. Plant Disease, 98:1407-1421.

Scherm B, Balmas V, Spanu F, Pani G, Delogu G, Pasquali M, Migheli Q, 2013. Fusarium culmorum: Causal Agent of Foot and Root Rot and Head Blight on Wheat. Molecular Plant Pathology, 14(4):323-341.

Streuter N, Moerschbacher B, Fischer Y, Noll U, Reisener H, 1989. Fructose-2,6-Bisphosphate in Wheat Leaves Infected with Stem Rust. Journal of Plant Physiology, 134:254-257.

Tarkowski LP, Van De Poel B, Höfte M, Ende WVD, 2019. Sweet Immunity: Inulin Boosts Resistance of Lettuce (Lactuca sativa) Against Grey Mold (Botrytis cinerea) in an Ethylene-Dependent Manner. International Journal of Molecular Science, 20: 105.

Trail F, 2009. For Blighted Waves of Grain: Fusarium graminearum in The Postgenomics Era. Plant Physiology, 149:103-110.

Troccoli A, Borreli GM, De Vita P, Fares C, Di Fonzo N, 2000. Durum Wheat Quality: A Multidisciplinary Concept. Journal of Cereal Science, 32:99-113.

Turnbull KM, Rahman S, 2002. Endosperm Texture in Wheat. Journal of Cereal Science, 36:327-337.

Xu X, Nicholson P, 2009. Community Ecology of Fungal Pathogens Causing Wheat Head Blight. Annual Review Phytopathology, 47:83-103.

Wang H, Sun S, Ge W, Zhao L, Hou B, Wang K, Lyu Z, Chen L, Xu S, Guo J. et al. 2020. Horizontal Gene Transfer of Fhb7 from Fungus Underlies Fusarium Head Blight Resistance in Wheat. Science. 368, eaba5435.

Wieser H, 2007. Chemistry of Gluten and Protein Orans, Food Microbiology, 24:115-119.

Zadoks JC, Chang TT, Konzak CF, 1974. A Decimal Code for the Growth Stages of Cereals. Weed Research, 14:415-421. 